\title{
Effects of spray-dried plasma protein product on early-lactation dairy cows
}

\author{
C. Lee, ${ }^{*}$ A. W. Tebbe, ${ }^{*}$ J. M. Campbell, $†$ and W. P. Weiss ${ }^{* 1}$ \\ *Department of Animal Sciences, Ohio Agricultural Research and Development Center, The Ohio State University, Wooster 44691 \\ †APC Inc., Ankeny, IA 50021
}

\section{ABSTRACT}

Spray-dried plasma protein (SDP) compared with blood meal (BM) may contain various functional and active components that may benefit animal health. The objective of this experiment was to investigate the effects of feeding SDP or BM on production and blood profile in dairy cows during the transition and early-lactation periods. Seventy-two Holstein cows at $14 \mathrm{~d}$ before calving were used in a randomized block design. During the prepartum period, cows were fed a typical late-gestation diet containing BM $(100 \mathrm{~g} / \mathrm{cow}$ per day; 100BM, $\mathrm{n}=24)$ or SDP (100 g/cow per day; 100SDP; $\mathrm{n}=48$ ). After calving, cows that were fed BM prepartum were fed a typical lactation diet formulated to provide $100 \mathrm{~g} / \mathrm{d}$ of $\mathrm{BM}(100 \mathrm{BM})$. Half the cows that were fed 100SDP prepartum were fed a lactation diet formulated to provide $100 \mathrm{~g} / \mathrm{d}$ of SDP (100SDP; $\mathrm{n}=$ 24 ), and half were fed a diet formulated to provide 400 $\mathrm{g} / \mathrm{d}$ of SDP (400SDP; $\mathrm{n}=24$ ) on a dry matter basis where SDP replaced BM (100SDP) or BM and soybean products (400SDP). All diets were balanced for crude protein concentration and metabolizable protein supply assuming BM and SDP were equal in rumen-degradable protein and rumen-undegradable protein. All data were analyzed using the MIXED procedure of SAS (SAS Institute Inc., Cary, NC) as a randomized block design where contrasts were made for 100BM versus 100SDP for prepartum variables and 100BM versus 100SDP and 100SDP versus 400SDP for postpartum variables. Prepartum supplementation of SDP had no effect on plasma fatty acids and $\beta$-hydroxybutyrate $(2 \mathrm{~d}$ before calving). Plasma fatty acids $(255 \pm 29 \mu \mathrm{Eq} / \mathrm{mL})$ and $\beta$-hydroxybutyrate $(675 \pm 70 \mu \mathrm{mol} / \mathrm{L})$ at 8 and $14 \mathrm{~d}$ of lactation were not affected by SDP in the diet. Feeding SDP at $100 \mathrm{~g} / \mathrm{d}$ compared with 100BM increased or tended to increase milk fat, protein, and lactose contents for 16 wk after parturition. Providing SDP at $400 \mathrm{~g} / \mathrm{d}$ in the diet increased milk yield (42 vs. 39

\footnotetext{
Received September 6, 2017.

Accepted February 23, 2018.

${ }^{1}$ Corresponding author: weiss.6@osu.edu
}

$\mathrm{kg} / \mathrm{d}$ ), energy-corrected milk (44 vs. $41 \mathrm{~kg} / \mathrm{d}$ ), energycorrected milk per kilogram of dry matter intake, and yields of milk fat (1.60 vs. $1.48 \mathrm{~kg} / \mathrm{d})$, protein (1.21 vs. $1.16 \mathrm{~kg} / \mathrm{d}$ ), and lactose compared with 100SDP. Body weight losses tended to be lower for 100SDP compared with 100BM without a difference between 100SDP and 400SDP. Plasma histidine concentration (d 14 of lactation) was lower for SDP compared with 100BM. In addition, plasma 1-methyl-L-histidine tended to be lower as inclusion rate of SDP increased. In conclusion, SDP at $400 \mathrm{~g} / \mathrm{d}$ increased milk and milk component yields without an increase in feed intake. Studies evaluating effects of functional and active compounds in SDP on gut microbiome, gut health, and immune functions may be needed to determine mode of action.

Key words: spray-dried plasma, transition, early lactation, dairy cow

\section{INTRODUCTION}

Dairy cows undergo negative energy and protein balance after parturition because of low DMI relative to milk production (Drackley, 1999; Bell et al., 2000). Therefore, additional nutrients [e.g., fatty acids (FA) and AA] from the body reservoir are mobilized to provide energy and AA to support milk production during early lactation. Negative energy balance is a risk factor for numerous health disorders, including ketosis, retained placenta, displaced abomasum, metritis, and mastitis (Drackley, 1999; Hailemariam et al., 2014). These disorders negatively affect animal welfare and can cause substantial economic losses to producers by increasing veterinary costs and reducing milk production and reproductive efficiency (Ametaj et al., 2012). Nutritional strategies that can improve energy and protein balance in early lactation, such as increasing DMI, metabolizable AA supplies, or health status (Drackley, 1999; Larsen et al., 2015), should result in improved animal welfare and greater profitability.

Blood by-products originate from the meat processing industry and can be a good source of nutrients (especially AA) when fed to livestock (Almeida et al., 2013). Blood meal (BM) and spray-dried plasma 
(SDP) are both blood byproducts, but the blood components (whole blood vs. plasma) and production processes (e.g., drying procedure) are different. Blood meal has been widely used as a valuable protein source (high RUP) for dairy cows, whereas SDP has not been evaluated as a feed ingredient especially for transition and early-lactation cows. Spray-dried plasma contains various functional and active components such as immune-related proteins, growth factors, and biologically active peptides (Campbell et al., 2008; Pérez-Bosque et al., 2016). Although direct comparisons between SDP and BM are limited, feeding SDP may provide more of those components to cows compared with BM, potentially improving health status of transition and early-lactating cows. For example, AA ileal digestibility in pigs was greater for SDP compared with BM (Almeida et al., 2013). When SDP replaced other protein sources (e.g., soybean products, dried skim milk, meat meal) in diets of pigs, calves, poultry, mice, and fish (van Dijk et al., 2001; Gisbert et al., 2015; Song et al., 2015; Beski et al., 2016), feed intake, BW gains, and immune function were improved. Improved dietary protein utilization with reduced AA catabolism in the gut has been observed in pigs fed a diet containing SDP (Jiang et al., 2000).

Because the functional proteins and nonfunctional proteins in SDP can benefit nutrient supplies and health of dairy cows, our hypothesis was that feeding SDP compared with BM to dairy cows during the transition and early-lactation periods would increase production and improve the quality of colostrum. In addition, we hypothesized that the effects of SDP would be doserelated.

\section{MATERIALS AND METHODS}

All procedures in this project that involved animals were approved by The Ohio State University Institutional Animal Care and Use Committee.

\section{Diets and Experimental Design}

A total of 72 prepartum cows (21 primiparous and 51 multiparous) were used. Cows were blocked into groups of 3 based on parity and expected calving date (17 blocks of multiparous and 7 blocks of primiparous). The experiment consisted of 2 phases: a prepartum phase and postpartum phase. During the prepartum phase, cows were moved to individual box stalls $14 \mathrm{~d}$ before anticipated calving and received 1 of 2 treatment diets. Both diets were essentially the same (Table 1) except that one diet contained ring-dried BM (Akey Inc., Lewisburg, OH) and the other contained SDP (APC Inc., Ankeny, IA) and a treated soybean meal. One cow in each block was randomly assigned to $\mathrm{BM}$ and 2 cows were assigned to SDP treatment. Cows were fed a fixed amount of silage and concentrate (containing either BM or SDP) once daily with essentially complete consumption by all cows so that cows consumed $100 \mathrm{~g}$ of either BM (100BM) or SDP (100SDP). Grass hay was provided to allow ad libitum intake by all cows (intake was measured). Cows remained in box stalls for $2 \mathrm{~d}$ after calving and then were moved to tiestalls. The first morning after calving, all cows were switched to early-lactation diets (Tables 2 and 3). Cows that were fed 100BM prepartum were switched to a diet that contained BM (100BM). One cow in each block that was fed SDP prepartum was fed a diet formulated to provide $100 \mathrm{~g} / \mathrm{d}$ of SDP (100SDP); the other cow in the block was fed a diet formulated to provide 400 $\mathrm{g} / \mathrm{d}$ of SDP (400SDP). Essentially, the only difference between the 100BM and 100SDP diet was that SDP replaced BM. For the 400SDP diet, SDP replaced both $\mathrm{BM}$ and soy products. A study demonstrated a positive effect of feeding $400 \mathrm{~g} / \mathrm{d}$ (Bach et al., 2017); however, because of potential cost, the $100 \mathrm{~g} / \mathrm{d}$ treatment was included because it likely would be more economically feasible for field application. During the prepartum period, 400SDP was not included as a treatment because diets could not be made isonitrogenous without significant modification of the diet and the necessary inclusion rate (approximately $4 \%$ of diet DM) could have restricted intake. All diets were formulated to be isonitrogenous and to provide the same amount of MP. During the first 25 DIM, cows received diets formulated with an assumed DMI of $17 \mathrm{~kg} / \mathrm{d}$. Target RDP, RUP, and MP (NRC, 2001) were 10.5, 6.5, and $11.5 \%$ of diet $\mathrm{DM}$, respectively (protein fractions of SDP were assumed to be equal to BM). Starting on 26 DIM, cows were fed diets that were formulated with an assumed DMI of $27.5 \mathrm{~kg} / \mathrm{d}$ with target RDP, RUP, and MP of $10.0,6.0$, and $11 \%$, respectively (Table 3 ). This was done to maintain target intakes of BM or SDP (i.e., 100,100 , or $400 \mathrm{~g} / \mathrm{d}$ ) throughout the experimental period. Dietary concentrations of BM, SDP, and alfalfa hay were reduced and whole cottonseed concentration was increased after 25 DIM. To keep diets as similar as possible, one base concentrate was fed to all cows and separate concentrate mixes for each treatment were blended at the time of TMR preparation (14.7 and 9.0\% of diet DM for fresh and early-lactation diets, respectively). All cows remained on the early-lactation diets until 120 DIM (16 wk). All diets (close-up, fresh, and early lactation) were formulated to provide nutrients meeting the requirements for cows according to NRC (2001). During the lactation phase, diets were mixed every morning $(0300 \mathrm{~h})$ and provided to individual cows ad libitum ( $5 \%$ orts) as a TMR with free access to 
water. All cows were milked in the milking parlor twice per day (0100 and $1300 \mathrm{~h}$ ).

\section{Sampling Procedures and Laboratory Analyses}

Feed offered and refused and milk yields (a.m. and p.m.) were measured daily for individual cows. Firstmilking colostrum was sampled from individual cows and assayed for $\operatorname{IgG}$ according to the procedure by Fahey and McKelvey (1965) and Mancini et al. (1965) and for total $\mathrm{N}$ using the Kjeldahl procedure (AOAC International, 2000; method 984.13.4.09). Milk was sampled weekly (a.m. and p.m.) and analyzed for fat, true protein, lactose (B2000 Infrared Analyzer, Bentley Instruments, Chaska, MN), and MUN (Skalar SAN

Table 1. Ingredient and nutrient composition of diets fed the last 10 d of gestation ${ }^{1}$

\begin{tabular}{lcc}
\hline & \multicolumn{2}{c}{ Treatment $^{2}$} \\
\cline { 2 - 3 } Item & $100 \mathrm{BM}$ & $100 \mathrm{SDP}$ \\
\hline Ingredient, \% of DM & 14.5 & 14.5 \\
Corn silage & 38.2 & 38.2 \\
Grass silage & 28.2 & 28.2 \\
Grass hay $^{3}$ & 4.74 & 4.58 \\
Corn grain & 4.13 & 4.13 \\
Bio-chlor $^{4}$ & 0 & 0.48 \\
Aminoplus & & 7.11 \\
Soyhulls & 7.42 & 1.84 \\
Minerals and vitamins & \\
Animal-vegetable fat & 1.84 & 0.20 \\
BM & 0.20 & - \\
SDP & 0.77 & 0.77 \\
Nutrient, \% of DM & - & \\
CP & & 12.1 \\
NDF & 12.1 & 1.02 \\
Ca & 54.0 & 0.36 \\
P & 1.02 & 0.35 \\
\hline
\end{tabular}

${ }^{1}$ Values are calculated from average intake of hay (amounts of all ingredients were fixed except hay, which was adjusted based on appetite of individual cows).

${ }^{2} 100 \mathrm{BM}=100 \mathrm{~g} / \mathrm{d}$ of blood meal; $100 \mathrm{SDP}=100 \mathrm{~g} / \mathrm{d}$ of spray-dried plasma protein.

${ }^{3}$ Grass hay was fed ad libitum. The proportion indicated was calculated based on the average intake of grass hay for individual cows.

${ }^{4}$ Bio-chlor (Church \& Dwight Inc., Princeton, NJ) was used to lower DCAD.

${ }^{5}$ Contained CP, $51 \%$ of DM; RDP, $28 \%$ of CP; RUP, $72 \%$ of CP (provided by the manufacturer, Ag Processing Inc., Omaha, NE).

${ }^{6}$ Premix contained $10.0 \%$ trace mineralized salt (Morton Salt Inc., Chicago, IL), 31.1\% limestone, 3.8\% magnesium oxide (Animag Prilled 30/100, Martin Marietta Magnesia Specialties LLC, Baltimore, MD), $8.0 \%$ sodium selenate premix (200 $\mathrm{mg}$ of $\mathrm{Se} / \mathrm{kg}$ ), $6.9 \%$ vitamin premix (formulated to provide 85,000 IU of vitamin A, 25,000 IU of vitamin $\mathrm{D}$, and 1,000 IU of vitamin E/d based on $12.5 \mathrm{~kg}$ of DMI), $31.1 \%$ biotin premix $(220 \mathrm{mg} / \mathrm{kg}), 0.19 \%$ copper sulfate $(252 \mathrm{~g}$ of $\mathrm{Cu} / \mathrm{kg}) 1.6 \%$ Zinpro 120 (Zinpro Corp., Eden Prairie, MN), and 0.5\% monensin (Rumensin-90, Elanco Animal Health, Greenfield, IN; formulated to provide $250 \mathrm{mg}$ of monensin/d).

${ }^{7}$ Ring-dried blood meal (Akey Inc., Lewisburg, OH).

${ }^{8}$ Spray-dried plasma protein (APC Inc., Ankeny, IA).
Plus, Skalar Inc., Norcross, GA) by DHI Cooperative Inc. (Columbus, $\mathrm{OH}$ ). An additional milk sample on d 21 of lactation was taken from individual cows to determine FA profile. Blood was collected from the tail vein of cows into heparinized tubes (BD Vacutainer; Becton Dickinson, Franklin Lakes, NJ) at -3 d before anticipated calving and 8 and $14 \mathrm{~d}$ of lactation. Plasma was separated immediately and frozen at $-20^{\circ} \mathrm{C}$ in separate vials until analysis. Plasma samples were analyzed for BHB ( $\beta$-Hydroxybutyrate LiquiColor No. 2440, Stanbio Laboratory, Boerne, TX) and FA [NEFA-HR(2), Wako Chemicals, Richmond, VA]. A subsample of plasma collected from only multiparous cows at $14 \mathrm{~d}$ of lactation was sent to Amino Acid Laboratory (UC Davis, Davis, CA) for complete AA analysis (Heinze et al., 2009).

Table 2. Ingredient composition of diets (\% of DM) fed to lactating cows

\begin{tabular}{|c|c|c|c|}
\hline \multirow[b]{2}{*}{ Ingredient } & \multicolumn{3}{|c|}{ Treatment $^{1}$} \\
\hline & 100BM & 100SDP & 400SDP \\
\hline \multicolumn{4}{|l|}{ First 25 DIM } \\
\hline Corn silage & 38 & 38 & 38 \\
\hline Alfalfa silage & 13 & 13 & 13 \\
\hline Alfalfa hay & 6 & 6 & 6 \\
\hline Whole cottonseed & 7 & 7 & 7 \\
\hline Corn grain & 16.3 & 16.1 & 17.0 \\
\hline Soybean meal, $48 \%$ CP & 4.1 & 4.1 & 3.9 \\
\hline Aminoplus $^{2}$ & 8.9 & 9.3 & 6.5 \\
\hline Soyhulls & 3.2 & 3.2 & 3.4 \\
\hline Animal-vegetable fat & 0.4 & 0.4 & 0.4 \\
\hline Minerals and vitamins ${ }^{3}$ & 2.5 & 2.3 & 2.4 \\
\hline $\mathrm{BM}^{4}$ & 0.6 & 0 & 0 \\
\hline $\mathrm{SDP}^{5}$ & 0 & 0.6 & 2.4 \\
\hline \multicolumn{4}{|l|}{$>25 \mathrm{DIM}$} \\
\hline Corn silage & 36 & 36 & 36 \\
\hline Alfalfa silage & 16 & 16 & 16 \\
\hline Alfalfa hay & 2 & 2 & 2 \\
\hline Whole cottonseed & 10 & 10 & 10 \\
\hline Corn grain & 18.5 & 18.3 & 18.8 \\
\hline Soybean meal, $48 \%$ CP & 3.1 & 3.1 & 3.0 \\
\hline Aminoplus $^{2}$ & 7.3 & 7.5 & 5.8 \\
\hline Soyhulls & 3.6 & 3.6 & 3.7 \\
\hline Animal-vegetable fat & 0.4 & 0.4 & 0.4 \\
\hline Minerals and vitamins ${ }^{3}$ & 2.74 & 2.74 & 2.86 \\
\hline $\mathrm{BM}^{4}$ & 0.36 & 0 & 0 \\
\hline $\mathrm{SDP}^{5}$ & 0 & 0.36 & 1.44 \\
\hline
\end{tabular}

${ }^{1} 100 \mathrm{BM}=100 \mathrm{~g} / \mathrm{d}$ of blood meal; $100 \mathrm{SDP}=100 \mathrm{~g} / \mathrm{d}$ of spray-dried plasma protein; 400SDP $=400 \mathrm{~g} / \mathrm{d}$ of spray-dried plasma protein.

${ }^{2}$ Contained CP, $51 \%$ of DM; RDP, $28 \%$ of CP; RUP, $72 \%$ of CP (provided by the manufacturer, Ag Processing Inc., Omaha, NE).

${ }^{3}$ Premix contained $19.6 \%$ trace mineral salt, $34.2 \%$ limestone, $4.1 \%$ magnesium oxide, $9.8 \%$ monosodium phosphate, $7.1 \%$ sodium selenate premix (200 mg of $\mathrm{Se} / \mathrm{kg}$ ), $6.9 \%$ vitamin premix (formulated to provide 90,000 IU of vitamin A, 25,000 IU of vitamin D, and $500 \mathrm{IU}$ of vitamin $\mathrm{E} / \mathrm{d}$ based on $18 \mathrm{~kg}$ of DMI), $16.3 \%$ biotin premix (220 $\mathrm{mg} /$ $\mathrm{kg}$ ), 1.2\% Zinpro 120 (Zinpro Corp., Eden Prairie, MN), and 0.33\% Rumensin-90 (Elanco Animal Health, Greenfield, IN; formulated to provide 300 and $420 \mathrm{mg}$ of monensin/d during the first $25 \mathrm{DIM}$ and $>25$ DIM, respectively).

${ }^{4}$ Ring-dried blood meal (Akey Inc., Lewisburg, OH).

${ }^{5}$ Spray-dried plasma protein (APC Inc., Ankeny, IA). 
Body weights of individual cows were measured at the start of the trial (14 d before anticipated calving), $2 \mathrm{~d}$ postcalving, and then every 2 wk. Body condition was scored by 2 trained persons for all cows at $2 \mathrm{~d}$ before anticipated calving, d 21, and d 110 of lactation.

Silages were sampled weekly and assayed for DM $\left(100^{\circ} \mathrm{C}\right.$ for $\left.24 \mathrm{~h}\right)$ to adjust the TMR for changes in DM. Individual feed ingredients were sampled weekly and composited monthly for chemical analyses. The composited silage samples were dried at $55^{\circ} \mathrm{C}$ for 48 $\mathrm{h}$ and ground through a 1-mm screen (Wiley mill, Arthur H. Thomas, Philadelphia, PA). Feed samples were analyzed for DM $\left(100^{\circ} \mathrm{C}\right.$ for $\left.48 \mathrm{~h}\right)$, ash $\left(600^{\circ} \mathrm{C}\right.$ muffle oven overnight), NDF using sodium sulfite and amylase (Ankom fiber analyzer, Ankom Technology, Fairport, $\mathrm{NY}$ ), $\mathrm{CP}$ (Kjeldahl $\mathrm{N} \times 6.25$; AOAC International, 2000; method 984.13.4.09), starch (Weiss and Wyatt, 2003), long-chain FA (Weiss and Wyatt, 2003), and major minerals by inductively coupled plasma spectrometry after ashing at $535^{\circ} \mathrm{C}$ followed by digestion with $15 \%$ nitric acid. Samples of BM and SDP $(n=2)$ were analyzed for complete AA composition at Agricultural Experiment Station Chemical Laboratories (University of Missouri, Columbia; Supplemental Table S1, https://doi.org/10.3168/jds.2017-13795). Milk FA were methylated using a 2-step procedure (Jenkins, 2000) after separating the milk fat layer. Fatty acids were then quantified by gas-liquid chromatography (5890A gas chromatograph; Hewlett Packard, Avondale, PA)

Table 3. Nutrient composition of diets (\% of DM unless noted) fed to lactating cows

\begin{tabular}{lccc}
\hline & \multicolumn{3}{c}{ Treatment $^{1}$} \\
\cline { 2 - 4 } Item & 100BM & 100SDP & $400 \mathrm{SDP}$ \\
\hline First 25 DIM & & & \\
DM, \% as fed & 57.0 & 57.0 & 57.0 \\
CP & 17.0 & 17.0 & 17.1 \\
NDF & 33.9 & 34.0 & 33.8 \\
Starch & 22.7 & 23.0 & 23.3 \\
Long-chain fatty acids & 4.4 & 4.4 & 4.4 \\
Ash & 7.1 & 7.1 & 7.1 \\
NE ${ }^{2}$ Mcal/kg & 1.69 & 1.69 & 1.67 \\
Ca & 1.06 & 1.05 & 1.07 \\
P & 0.43 & 0.44 & 0.45 \\
>25 DIM & & & \\
DM, \% as fed & 58.6 & 58.6 & 58.6 \\
CP & 16.1 & 16.1 & 16.1 \\
NDF & 34.2 & 34.2 & 34.1 \\
Starch & 23.8 & 24.0 & 24.2 \\
Long-chain fatty acids & 4.9 & 4.9 & 4.9 \\
Ash & 7.1 & 7.2 & 7.2 \\
NE ${ }^{2}{ }^{2}$ Mcal/kg & 1.63 & 1.62 & 1.62 \\
Ca & 1.12 & 1.12 & 1.13 \\
P & 0.44 & 0.45 & 0.45
\end{tabular}

${ }^{1} 100 \mathrm{BM}=100 \mathrm{~g} / \mathrm{d}$ of blood meal; $100 \mathrm{SDP}=100 \mathrm{~g} / \mathrm{d}$ of spray-dried plasma protein; $400 \mathrm{SDP}=400 \mathrm{~g} / \mathrm{d}$ of spray-dried plasma protein.

${ }^{2}$ Estimated using the NRC (2001) model with treatment-average DMI. with a CP-SIL88 capillary column $(100 \mathrm{~m} \times 0.25 \mathrm{~mm}$ $\times 0.2 \mathrm{~mm}$ film thickness; Varian Inc., Palo Alto, CA). Conditions were as follows: injector temperature, $250^{\circ} \mathrm{C}$; flame ionization detector, $255^{\circ} \mathrm{C}$; hydrogen carrier gas at $0.8 \mathrm{~mL} / \mathrm{min}$; detector make-up gas $\left(\mathrm{N}_{2}\right)$ at $20 \mathrm{~mL} /$ min; and injector split ratio, 75:1. Orts were sampled 3 times per cow around 21,60 , and $90 \mathrm{~d}$ of lactation and were assayed for $\mathrm{DM}\left(100^{\circ} \mathrm{C}\right.$ oven for $\left.48 \mathrm{~h}\right)$ to calculate DMI.

\section{Calculations and Statistical Analyses}

Two cows (1 cow on 100BM and 1 cow on SDP prepartum) were removed from the experiment at or before calving for health reasons. A cow fed 100BM died at 14 DIM (necropsy could not determine cause of death), and only prepartum data were used for that cow. Another cow on 100SDP was removed after $28 \mathrm{~d}$ of lactation because of severe mastitis. Data from that cow were included in the prepartum analysis and on production data up to $21 \mathrm{~d}$.

The experiment was divided into prepartum and postpartum phases, but the statistical models were similar. Because milk was sampled weekly, DMI and milk yields were averaged by week and weekly means were statistically analyzed. Production data postpartum were further divided into a fresh period (wk 1-3) and early lactation (wk 4-16). Production data, milk FA, and plasma FA and BHB data were analyzed with the MIXED procedure of SAS version 9.4 (SAS Institute Inc., Cary, NC). The model included the fixed effects of treatment (2 treatments prepartum and 3 treatments postpartum), parity, time (repeated variable), all 2-way and 3-way interactions between fixed effects, and days on treatment before calving as a covariate and the random effect of block nested within parity. To directly test our hypotheses, postpartum treatment effects were separated a priori into 2 nonorthogonal contrasts: (1) effect of source of supplemental protein at equal inclusion rates (100BM vs. 100SDP) and (2) effect of inclusion rate of SDP (100SDP vs. 400SDP). Body weights and BCS measured before calving (i.e., before treatments were imposed) were used as a covariate to adjust for their subsequent postpartum measures of BW and BCS. The time variable for DMI was day prepartum, and week was used for milk and DMI data postpartum. Time for BW, BCS, and blood data varied based on measurement or sampling schedule (described above). The autoregressive covariance structure was used for all analyses except for BW and BCS, for which the unstructured covariance structure was used based on the lowest Bayesian information criterion. Interactions of treatment $x$ time or parity $x$ time were examined using the SLICE option. Somatic cell count 
Table 4. Effect of feeding spray-dried plasma (SDP) or blood meal (BM) on health events

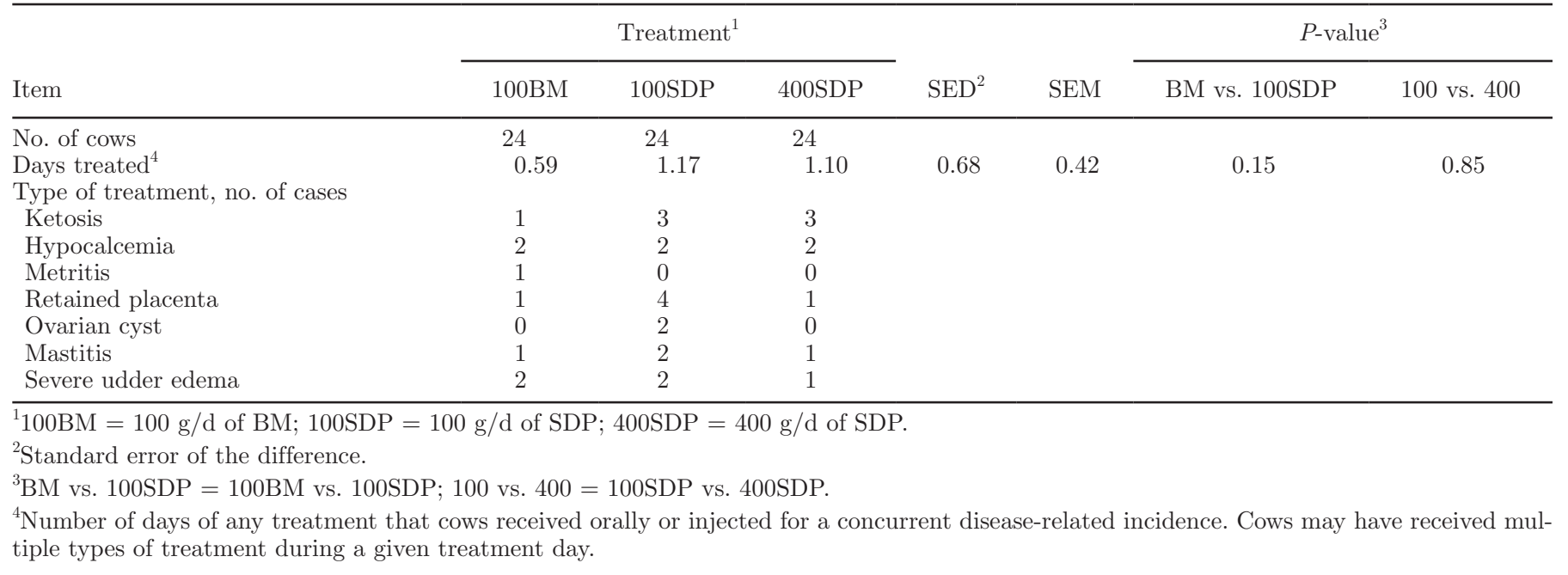

was $\log _{10}$ transformed before analysis and was not back transformed. Reproduction measures, calf birth weight (model included calf sex), plasma AA, colostrum composition, and prepartum blood data were analyzed with a similar model, except it did not include any time effects. Plasma AA were analyzed for multiparous cows only; therefore, parity was not included in that statistical analysis. Twins and stillbirths were not included in the birth weight analysis. All denominator degrees of freedom were adjusted using the Kenward-Roger option. Because of unbalanced replication of treatments, the highest standard error of the mean and standard error of the difference are reported for each dependent variable.

\section{RESULTS}

For prepartum data, 24 cows fed 100BM and 48 cows fed 100SDP were used. For the fresh period ( $\leq 21$ DIM), 23,24 , and 24 cows were on the 100BM, 100SDP, and 400SDP diets, respectively, and 23, 23, and 24 cows completed the experiment for 100BM, 100SDP, and 400SDP diets, respectively. An inadequate number of health events occurred for statistical analysis of treatment effects; therefore, all health events were combined and days treated were calculated. Dietary treatment did not affect days that cows received veterinary treatment (Table 4). As planned, all diets within a phase had essentially the same chemical composition (Tables 1 and 3 ) and met or exceeded NRC (2001) recommendations. Average intakes of test products during the lactation phase were close to target values. Target intakes were $100 \mathrm{~g} / \mathrm{d}$ for BM and 100 and $400 \mathrm{~g} / \mathrm{d}$ for 100SDP and 400SDP, respectively; actual average intakes during the fresh period were $107(\mathrm{SD}=17) \mathrm{g} / \mathrm{d}$ of $\mathrm{BM}$ and 113
$(\mathrm{SD}=14)$ and $432(\mathrm{SD}=54) \mathrm{g} / \mathrm{d}$ of SDP. During the early-lactation phase, actual intakes were $93(\mathrm{SD}=11)$ $\mathrm{g} / \mathrm{d}$ of $\mathrm{BM}$ and $94(\mathrm{SD}=11)$ and $385(\mathrm{SD}=40) \mathrm{g} / \mathrm{d}$ of SDP.

\section{Prepartum Period}

During the prepartum period, DMI averaged 10.1 and $10.4 \mathrm{~kg} / \mathrm{d}$ for $100 \mathrm{BM}$ and 100SDP and was not affected by treatment $(P=0.39$; data not shown), and no treatment $\times$ day interaction was observed. Plasma FA and BHB concentrations $2 \mathrm{~d}$ before calving were not different $(P \geq 0.78)$ between 100BM and 100SDP, and treatment did not affect $(P \geq 0.28)$ calf birth $\mathrm{BW}$ or colostrum composition (Table 5 ).

\section{Postpartum Period}

During the first $21 \mathrm{~d}$ of lactation, DMI was greater for 100SDP versus 100BM $(P<0.01)$ without a difference between 100 and 400SDP (Table 6). A significant interaction between treatment and day $(P<0.05)$ for DMI was observed. Source of protein (100BM vs. 100SDP) affected only milk protein percentage, which was greater $(P=0.03)$ for 100SDP than 100BM without a difference between 100 and 400SDP. Cows fed 400SDP produced more milk $(P=0.01)$ and tended to have greater MUN $(P=0.08)$ than cows fed 100SDP. The effect of inclusion rate of SDP on milk yield was consistent across time. Lactose percentage tended to be lower $(P=0.08)$ for 400SDP versus 100SDP.

During the early-lactation phase (22-120 DIM), DMI was not different among treatments. Cows fed 100SDP produced milk with greater $(P \leq 0.08)$ concentrations of milk fat and protein than cows fed 100BM (Table 
Table 5. Effect of feeding spray-dried plasma (SDP) or blood meal (BM) on prepartum blood metabolites, calf BW, and colostrum composition

\begin{tabular}{|c|c|c|c|c|c|c|}
\hline Item & \multicolumn{2}{|c|}{ Treatment $^{1}$} & $\mathrm{SED}^{2}$ & SEM & \multicolumn{2}{|c|}{$P$-value } \\
\hline \multicolumn{7}{|l|}{$\overline{\text { Blood }^{3}}$} \\
\hline $\mathrm{FA}>500 \mu \mathrm{Eq} / \mathrm{mL},{ }^{4} \%$ & 3.7 & 10.8 & 7.7 & 6.8 & 0.37 & 0.32 \\
\hline $\mathrm{BHB}, \mu \mathrm{mol} / \mathrm{L}$ & 415.9 & 422.5 & 40.3 & 33.6 & 0.85 & 0.81 \\
\hline $\mathrm{BHB}>1,200 \mu \mathrm{mol} / \mathrm{L},{ }^{4} \%$ & 0 & 0 & 0 & 0 & - & - \\
\hline $\operatorname{IgG}$ & 7.08 & 7.09 & 0.56 & 0.48 & 0.99 & 0.30 \\
\hline TS & 27.2 & 26.1 & 0.98 & 0.81 & 0.28 & 0.09 \\
\hline
\end{tabular}

${ }^{1} 100 \mathrm{BM}=100 \mathrm{~g} / \mathrm{d}$ of BM; $100 \mathrm{SDP}=100 \mathrm{~g} / \mathrm{d}$ of SDP.

${ }^{2}$ Standard error of the difference.

${ }^{3}$ Collected on d 2 before expected parturition. FA = fatty acid.

${ }^{4} 500 \mathrm{mEq} / \mathrm{mL}$ of fatty acids (FA) and 1,200 $\mathrm{mol} / \mathrm{L}$ of BHB were used as cut-off values for subclinical ketosis (Ospina et al., 2010).

${ }^{5}$ Interaction of sex $\times$ parity $\times$ treatment, $0.05<P<0.10$.

7). Those cows also had lower SCC $(P<0.06)$, but SCC was low for all treatments. Conversely, feeding the greater amount of SDP (i.e., 400SDP vs. 100SDP) reduced concentrations of most milk components; however, yields of most milk components were greater for cows fed 400SDP than for those fed 100SDP. The same results were observed when the whole postpartum period (3-120 DIM) was examined (Table 8). As expected, time effects $(P<0.05)$ for DMI and milk yield and composition were observed (Tables 6, 7, and 8). Some time $\times$ treatment interactions $(P<0.10)$ were observed for production variables, but treatment ef-

Table 6. Effects of feeding spray-dried plasma (SDP) or blood meal (BM) on intake, production, and blood metabolites from 3 to 21 DIM ${ }^{1}$

\begin{tabular}{|c|c|c|c|c|c|c|c|}
\hline \multirow[b]{2}{*}{ Item } & \multicolumn{3}{|c|}{ Treatment $^{2}$} & \multirow[b]{2}{*}{$\mathrm{SED}^{3}$} & \multirow[b]{2}{*}{ SEM } & \multicolumn{2}{|c|}{$P$-value ${ }^{4}$} \\
\hline & $100 \mathrm{BM}$ & 100SDP & 400SDP & & & BM vs. 100SDP & 100 vs. 400 \\
\hline DMI, $\mathrm{kg} / \mathrm{d}$ & 18.0 & 19.1 & 19.1 & 0.43 & 0.36 & 0.01 & 0.99 \\
\hline $\mathrm{BW}, \mathrm{kg}$ & 669 & 667 & 669 & 6.6 & 4.7 & 0.86 & 0.83 \\
\hline BW change, $\mathrm{kg} / \mathrm{wk}$ & -2.8 & -2.0 & -3.1 & 0.52 & 0.39 & 0.11 & 0.04 \\
\hline Milk, kg/d & 35.1 & 34.6 & 37.5 & 1.07 & 0.86 & 0.64 & 0.01 \\
\hline $\mathrm{ECM}, \mathrm{kg} / \mathrm{d}$ & 40.1 & 39.3 & 42.0 & 2.02 & 1.44 & 0.68 & 0.19 \\
\hline ECM/DMI & 2.22 & 2.11 & 2.24 & 0.10 & 0.08 & 0.25 & 0.19 \\
\hline Milk fat, $\%$ & 4.11 & 4.29 & 4.23 & 0.20 & 0.14 & 0.34 & 0.75 \\
\hline Milk protein, $\%$ & 3.15 & 3.29 & 3.21 & 0.06 & 0.05 & 0.03 & 0.22 \\
\hline Milk lactose, $\%$ & 4.96 & 4.90 & 4.83 & 0.04 & 0.03 & 0.24 & 0.08 \\
\hline Milk energy, ${ }^{5}$ Mcal $/ \mathrm{kg}$ & 0.75 & 0.78 & 0.76 & 0.02 & 0.01 & 0.12 & 0.46 \\
\hline Milk fat, kg/d & 1.54 & 1.50 & 1.61 & 0.11 & 0.08 & 0.73 & 0.34 \\
\hline Milk protein, ${ }^{6} \mathrm{~kg} / \mathrm{d}$ & 1.15 & 1.14 & 1.20 & 0.04 & 0.03 & 0.88 & 0.17 \\
\hline Milk lactose, $\mathrm{kg} / \mathrm{d}$ & 1.79 & 1.71 & 1.83 & 0.07 & 0.05 & 0.29 & 0.12 \\
\hline Milk energy, ${ }^{5} \mathrm{Mcal} / \mathrm{d}$ & 27.9 & 27.2 & 28.9 & 1.40 & 1.00 & 0.62 & 0.21 \\
\hline MUN, mg/dL & 13.5 & 13.5 & 14.9 & 0.77 & 0.76 & 0.99 & 0.08 \\
\hline $\mathrm{SCC} \times 1,000 \log _{10} / \mathrm{mL}$ & 1.68 & 1.53 & 1.58 & 0.12 & 0.09 & 0.21 & 0.66 \\
\hline Plasma FA, $\mu \mathrm{Eq} / \mathrm{mL}$ & 245.1 & 215.2 & 253.2 & 33.1 & 25.1 & 0.36 & 0.25 \\
\hline Plasma FA $>500 \mu \mathrm{Eq} / \mathrm{mL}^{7} \%$ & 6.7 & 1.7 & 5.9 & 5.2 & 3.8 & 0.33 & 0.43 \\
\hline Plasma BHB, $\mu \mathrm{mol} / \mathrm{L}$ & 830.7 & 787.8 & 802.6 & 135.0 & 96.6 & 0.75 & 0.91 \\
\hline Plasma $\mathrm{BHB}>1,200 \mu \mathrm{mol} / \mathrm{L},{ }^{7} \%$ & 12.1 & 13.0 & 11.4 & 7.8 & 5.5 & 0.98 & 0.94 \\
\hline
\end{tabular}

${ }^{1}$ Significant time effect $(P<0.05)$ was observed for all variables except milk protein and lactose yields and MUN.

${ }^{2} 100 \mathrm{BM}=100 \mathrm{~g} / \mathrm{d}$ of BM; $100 \mathrm{SDP}=100 \mathrm{~g} / \mathrm{d}$ of SDP; 400SDP $=400 \mathrm{~g} / \mathrm{d}$ of SDP.

${ }^{3}$ Standard error of the difference.

${ }^{4} \mathrm{BM}$ vs. $100 \mathrm{SDP}=100 \mathrm{BM}$ vs. $100 \mathrm{SDP} ; 100$ vs. $400=100 \mathrm{SDP}$ vs. $400 \mathrm{SDP}$.

${ }^{5}$ Calculated based on NRC (2001).

${ }^{6}$ Interaction of week $\times$ treatment, $0.05<P<0.10$.

${ }^{7} 500 \mathrm{mEq} / \mathrm{mL}$ of fatty acids (FA) and 1,200 $\mu \mathrm{mol} / \mathrm{L}$ of BHB were used as cut-off values for subclinical ketosis (Ospina et al., 2010). 
Table 7. Effect of feeding spray-dried plasma (SDP) or blood meal (BM) on intake and production from 21 to $120 \mathrm{DIM}^{1}$

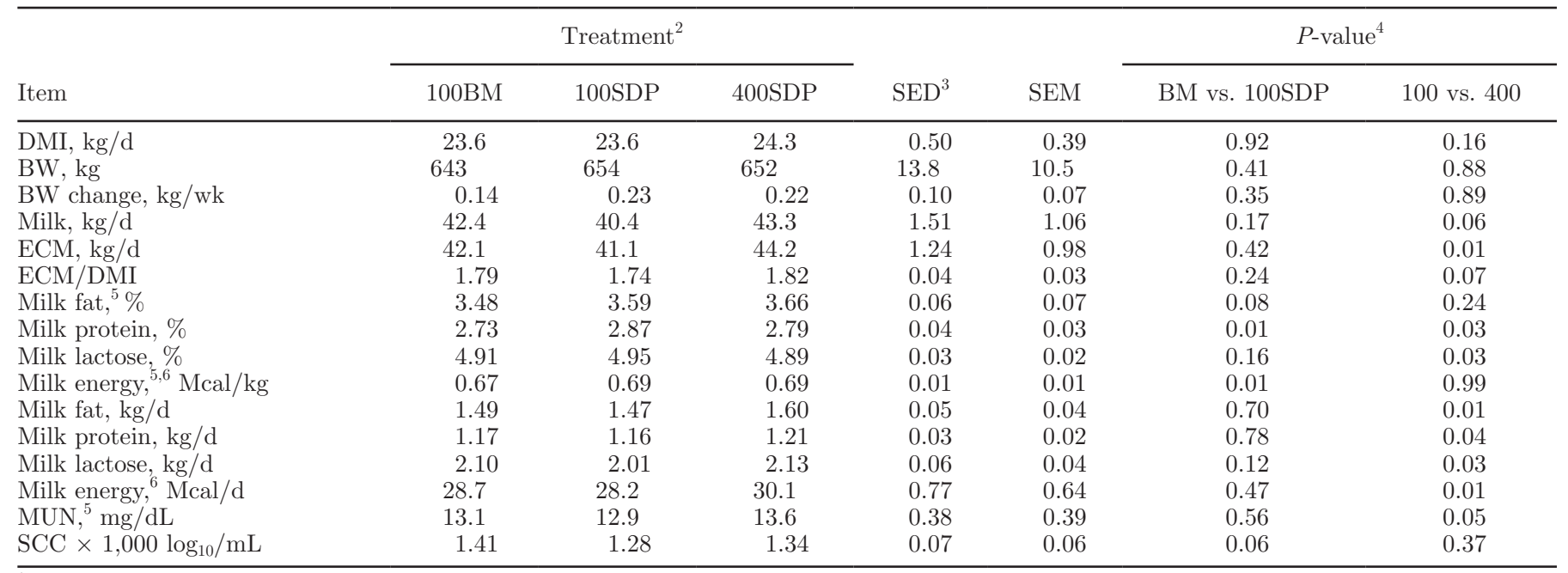

${ }^{1}$ Significant time effect $(P<0.05)$ was observed for all variables except ECM, milk fat $(\%)$, milk protein yield, milk energy content and yield, MUN, and SCC.

${ }^{2} 100 \mathrm{BM}=100 \mathrm{~g} / \mathrm{d}$ of BM; $100 \mathrm{SDP}=100 \mathrm{~g} / \mathrm{d}$ of SDP; 400SDP $=400 \mathrm{~g} / \mathrm{d}$ of SDP.

${ }^{3}$ Standard error of the difference.

${ }^{4} \mathrm{BM}$ vs. $100 \mathrm{SDP}=100 \mathrm{BM}$ vs. $100 \mathrm{SDP} ; 100$ vs. $400=100 \mathrm{SDP}$ vs. $400 \mathrm{SDP}$.

${ }^{5}$ Interaction of parity $\times$ treatment, $0.05<P<0.10$.

${ }^{6}$ Calculated based on NRC (2001).

Table 8. Effect of feeding spray-dried plasma (SDP) or blood meal (BM) on intake and production for first 120 DIM $^{1}$

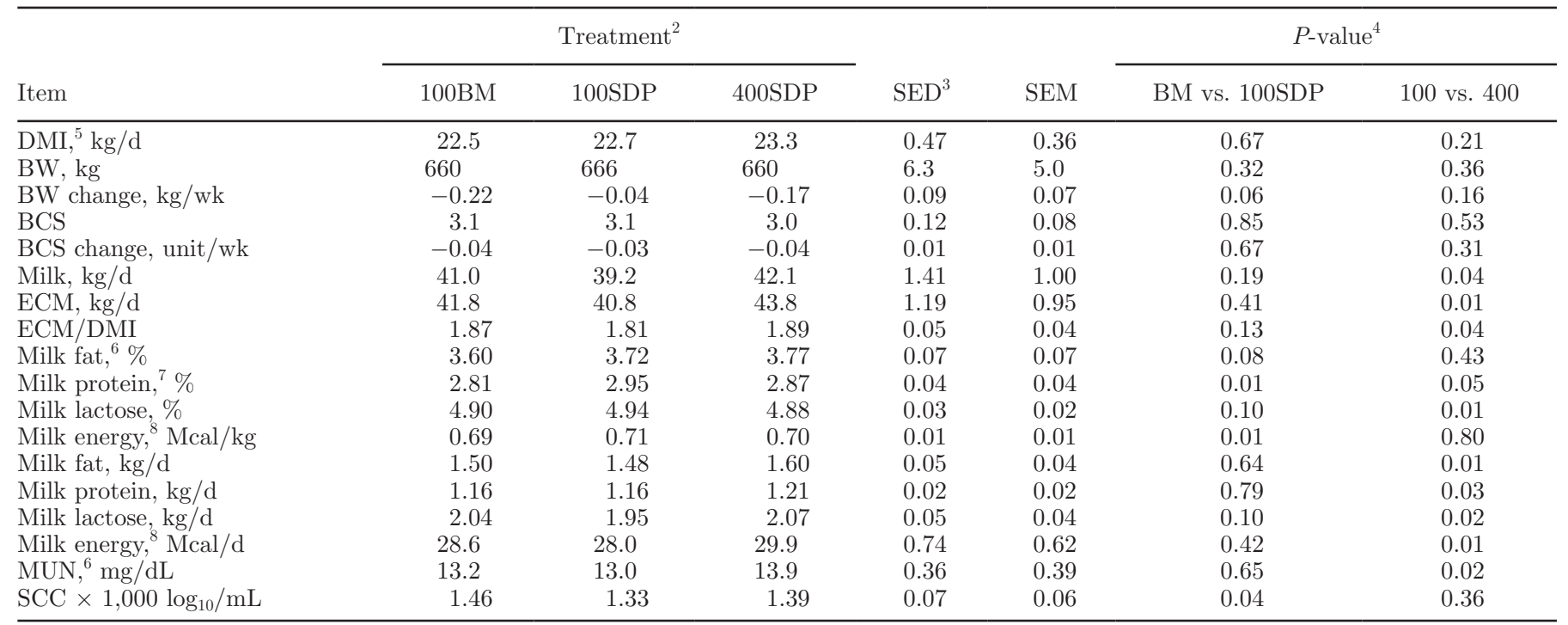

${ }^{1}$ Significant time effect $(P<0.05)$ was observed for all variables except yields of milk fat, protein, and lactose.

${ }^{2} 100 \mathrm{BM}=100 \mathrm{~g} / \mathrm{d}$ of BM; $100 \mathrm{SDP}=100 \mathrm{~g} / \mathrm{d}$ of SDP; $400 \mathrm{SDP}=400 \mathrm{~g} / \mathrm{d}$ of SDP.

${ }^{3}$ Standard error of the difference.

${ }^{4} \mathrm{BM}$ vs. $100 \mathrm{SDP}=100 \mathrm{BM}$ vs. $100 \mathrm{SDP} ; 100$ vs. $400=100 \mathrm{SDP}$ vs. $400 \mathrm{SDP}$.

${ }^{5}$ Interaction of week $\times$ treatment, $P<0.05$.

${ }^{6}$ Interaction of parity $\times$ treatment, $0.05<P<0.10$.

${ }^{7}$ Interaction of week $\times$ treatment, $0.05<P<0.10$.

${ }^{8}$ Calculated based on NRC (2001). 


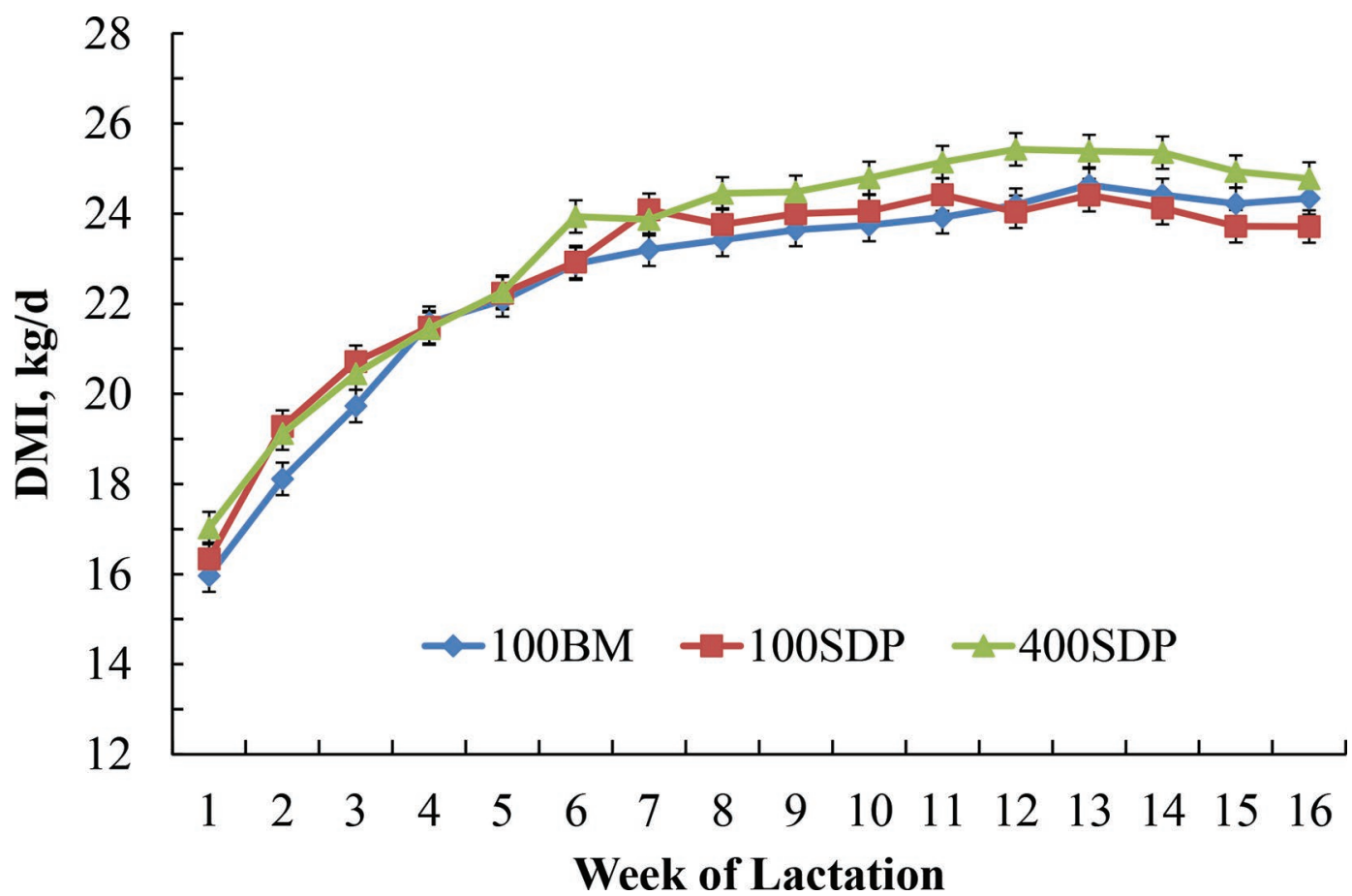

Figure 1. Effect of feeding spray-dried plasma or blood meal on weekly DMI during the first $120 \mathrm{~d}$ of lactation. $100 \mathrm{BM}=100 \mathrm{~g} / \mathrm{d}$ of blood meal; $100 \mathrm{SDP}=100 \mathrm{~g} / \mathrm{d}$ of spray-dried plasma protein; 400SDP $=400 \mathrm{~g} / \mathrm{d}$ of spray-dried plasma protein. Interaction between treatment and week, $P<0.05$. Vertical bars represent SEM. Color version available online.

fects generally were consistent during the experiment was greater $(P=0.04)$ for cows fed 400SDP than for (Figures 1 and 2$)$ and only significant interactions $(P<$ those fed 100SDP without a difference between 100BM $0.05)$ are discussed. Feed efficiency (ECM/DMI, $\mathrm{kg} / \mathrm{kg}$ ) and 100SDP (Table 8).

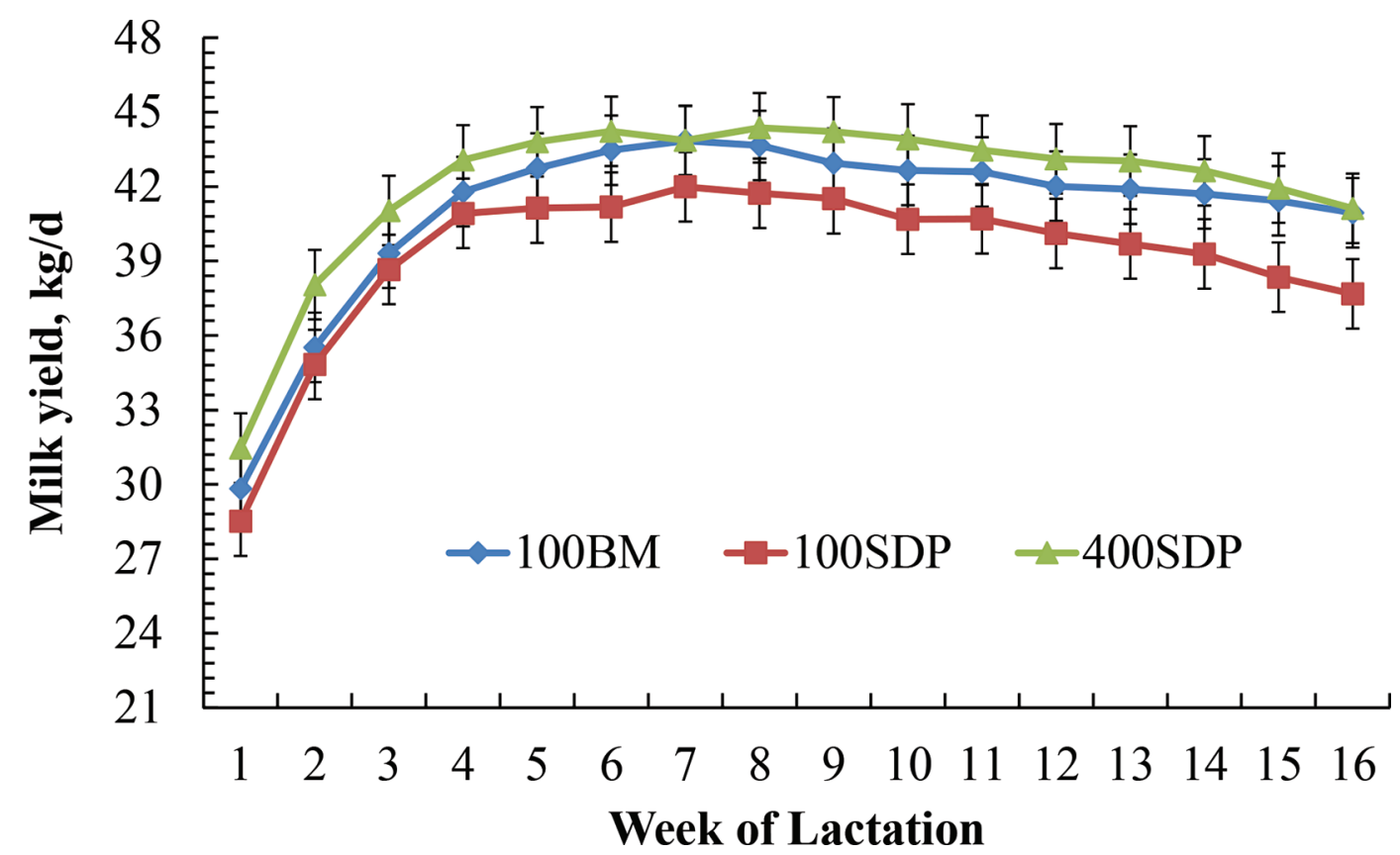

Figure 2. Effect of feeding spray-dried plasma or blood meal on weekly milk yields during the first $120 \mathrm{~d}$ of lactation. $100 \mathrm{BM}=100 \mathrm{~g} / \mathrm{d}$ of blood meal; 100SDP $=100 \mathrm{~g} / \mathrm{d}$ of spray-dried plasma protein; 400SDP $=400 \mathrm{~g} / \mathrm{d}$ of spray-dried plasma protein. Vertical bars represent SEM. Color version available online. 
As expected, on average cows on all treatments lost BW after parturition (i.e., negative energy balance) and cows on average gained BW gradually as lactation progressed. Cows fed 100SDP lost less BW $(P=0.06)$ compared with 100BM during the 120-d experiment (Table 8). Cows fed 400SDP lost more weight $(P=$ $0.04)$ during the first $21 \mathrm{~d}$ of lactation than did cows fed 100SDP (Table 6), but over the entire experiment, BW change was not affected $(P=0.16)$ by inclusion rate (Table 8).

Treatment had only minor effects on concentrations of AA in plasma in multiparous cows (Table 9). For EAA, cows fed 100BM had greater $(P=0.01)$ concentrations of histidine and tended to have greater $(P$ $=0.09)$ valine concentrations than cows fed 100SDP. Increasing inclusion rate of SDP increased $(P \leq 0.03)$ concentrations of threonine and tryptophan. Inclusion rate of SDP increased or tended to increase several NEAA. Plasma 1-methyl-L-histidine tended to be lower $(P=0.09)$ as inclusion rate of SDP increased, but treatment had no effect on 3-methyl-L-histidine.

Cows fed 100SDP tended to produce milk fat with greater $(P=0.06)$ concentrations of shorter-chain FA $(<16 \mathrm{C})$ and lower $(P=0.05)$ concentrations of long-chain FA $(>16 \mathrm{C})$ and trans FA $(P<0.04)$ than cows fed 100BM. The concentrations of cis-9,trans-11 and cis-10,trans-12 CLA decreased $(P \leq 0.04)$ with increases in inclusion of SDP.

\section{DISCUSSION}

Various measures of immune function have been improved when SDP was fed to nonruminants (Dritz et al., 1996; Song et al., 2015). However, in our experiment, feeding SDP rather than BM had no effect on any measure associated with the prepartum period, including blood metabolites, calf BW, and colostrum composition. Although few health problems (e.g., ketosis, hypocalcemia, metritis, retained placenta) were observed in this study, health events were not affected by treatment.

Replacing BM with SDP increased DMI in the early-lactation period $(\leq 21 \mathrm{~d})$, but that effect did not continue as lactation progressed. To our knowledge, no studies that directly compared SDP with BM in lactating cows are available. Replacing soybean meal with a mixture of $\mathrm{BM}$ and corn gluten meal (3\% inclusion rate for BM) did not affect DMI of dairy cows in one study (De Gracia et al., 1989); however, in another study (Pires et al., 1996) cows fed a diet with $2.7 \%$ BM had $11 \%$ lower DMI than cows fed a soybean meal-based diet. Grant and Haddad (1998) provided diets differ-

Table 9. Effect of feeding spray-dried plasma (SDP) or blood meal (BM) on plasma AA at 14 DIM $^{1}$

\begin{tabular}{|c|c|c|c|c|c|c|c|}
\hline \multirow[b]{2}{*}{$\mathrm{AA}, \mu \mathrm{mol} / \mathrm{L}$} & \multicolumn{3}{|c|}{ Treatment $^{2}$} & \multirow[b]{2}{*}{$\mathrm{SED}^{3}$} & \multirow[b]{2}{*}{ SEM } & \multicolumn{2}{|c|}{$P$-value ${ }^{4}$} \\
\hline & 100BM & 100SDP & 400SDP & & & BM vs. 100SDP & 100 vs. 400 \\
\hline$\overline{\text { Arginine }}$ & 62.1 & 57.1 & 63.4 & 6.80 & 4.79 & 0.46 & 0.35 \\
\hline Histidine & 58.5 & 45.7 & 47.7 & 4.48 & 3.15 & 0.01 & 0.65 \\
\hline Isoleucine & 116.4 & 120.2 & 135.4 & 18.4 & 13.2 & 0.84 & 0.41 \\
\hline Leucine & 127.5 & 102.2 & 123.6 & 15.9 & 11.2 & 0.13 & 0.19 \\
\hline Lysine & 71.1 & 64.1 & 70.7 & 6.37 & 5.16 & 0.29 & 0.31 \\
\hline Methionine & 18.1 & 16.9 & 20.0 & 2.01 & 1.41 & 0.56 & 0.12 \\
\hline Phenylalanine & 48.6 & 43.7 & 45.2 & 4.22 & 2.97 & 0.25 & 0.73 \\
\hline Threonine & 95.7 & 79.4 & 107.4 & 10.9 & 7.69 & 0.15 & 0.02 \\
\hline Tryptophan & 35.1 & 31.3 & 37.2 & 2.42 & 2.04 & 0.14 & 0.03 \\
\hline Valine & 248.5 & 203.0 & 231.9 & 25.7 & 20.1 & 0.09 & 0.27 \\
\hline EAA & 881.2 & 763.9 & 882.5 & 74.8 & 56.4 & 0.13 & 0.12 \\
\hline Alanine & 2.97 & 2.21 & 2.67 & 0.61 & 0.43 & 0.23 & 0.45 \\
\hline Aspartate & 14.6 & 13.6 & 15.3 & 1.02 & 0.72 & 0.33 & 0.10 \\
\hline Asparagine & 42.0 & 37.9 & 43.0 & 4.20 & 2.96 & 0.33 & 0.22 \\
\hline Glutamate & 56.1 & 52.9 & 59.3 & 2.97 & 2.29 & 0.29 & 0.04 \\
\hline Glutamine & 243.5 & 236.4 & 305.0 & 16.6 & 11.7 & 0.67 & 0.01 \\
\hline Glycine & 553.1 & 446.2 & 503.3 & 55.1 & 38.7 & 0.06 & 0.30 \\
\hline Proline & 76.2 & 68.6 & 76.4 & 8.78 & 6.18 & 0.39 & 0.37 \\
\hline Serine & 138.1 & 117.3 & 123.9 & 25.3 & 17.8 & 0.42 & 0.79 \\
\hline Tyrosine & 40.1 & 39.6 & 44.2 & 4.01 & 3.09 & 0.90 & 0.26 \\
\hline NEAA & 1,390 & 1,213 & 1,402 & 112.4 & 79.1 & 0.13 & 0.10 \\
\hline 1-Methyl-L-histidine & 14.3 & 13.9 & 12.3 & 0.98 & 0.69 & 0.74 & 0.09 \\
\hline 3-Methyl-L-histidine & 5.4 & 4.7 & 5.1 & 0.63 & 0.44 & 0.26 & 0.53 \\
\hline
\end{tabular}

${ }^{1}$ Only multiparous cows were sampled for AA analysis.

${ }^{2} 100 \mathrm{BM}=100 \mathrm{~g} / \mathrm{d}$ of BM; $100 \mathrm{SDP}=100 \mathrm{~g} / \mathrm{d}$ of SDP; $400 \mathrm{SDP}=400 \mathrm{~g} / \mathrm{d}$ of SDP.

${ }^{3}$ Standard error of the difference.

${ }^{4} \mathrm{BM}$ vs. $100 \mathrm{SDP}=100 \mathrm{BM}$ vs. $100 \mathrm{SDP} ; 100$ vs. $400=100 \mathrm{SDP}$ vs. $400 \mathrm{SDP}$. 
ing in protein concentrations $(17.5$ and $19.4 \% \mathrm{CP}$ in dietary $\mathrm{DM})$ to dairy cows and found no differences in DMI when the mixture (4\% in dietary DM) of BM and feather meal (15:85 on a DM basis) replaced soybean meal in a $17.5 \% \mathrm{CP}$ diet. However, in diets with $19.4 \% \mathrm{CP}$, the mixture of $\mathrm{BM}$ and feather meal (4\% in dietary DM) decreased DMI by $14 \%$ compared with a soybean meal-based diet. Those studies indicate that inclusion of $\mathrm{BM}$ in a dairy ration either depresses or does not affect DMI. Because of the treatments used in the current study, we cannot determine whether BM depressed DMI in early lactation or SDP stimulated DMI because there was no diet without animal protein. However, greater DMI for SDP versus BM was observed only during the first $21 \mathrm{~d}$ of lactation when concentration of BM or SDP was about twice as high as in the later-lactation diets (this was done to maintain target intakes of BM and SDP because of expected lower DMI during this period).

When SDP replaced BM (both at $100 \mathrm{~g} / \mathrm{d}$ ), concentrations of milk fat and protein increased, but this may have been caused by dilution because yield of those components did not differ between those diets. Over the entire experimental period, increasing the inclusion rate of SDP (i.e., 100SDP vs. 400SDP) increased yields of milk and milk components but did not increase DMI. The additional yield of milk and milk components probably did not occur at the expense of body reserves because change in BW and BCS was not affected by SDP. The lack of difference in BHB, FA, and 3-methylhistidine (a marker of body protein mobilization) among treatments further supports similar mobilization of body reserves. This suggests potential improvement in either digestive or metabolic efficiency when $400 \mathrm{~g}$ of SDP was fed. Piglets fed SDP had better gut health and improved growth performance (van Dijk et al., 2001). The presence of immune-related proteins, growth factors, biologically active peptides, and so on in the plasma protein was suggested as a possible mode of action, potentially by preventing pathogens from damaging the gut (Coffey and Cromwell, 1995). Spraydried plasma increased feed intake and growth in pigs (Dritz et al., 1996) and pregnancy rates in mice (Song et al., 2015); based on measures taken in those experiments, reduced inflammation may have been involved. Feeding SDP to gilthead sea bream improved intestinal and serum innate immune function and antioxidative activities, resulting in increases in growth performance (Gisbert et al., 2015).

The SDP may have provided functional proteins, but it also supplied nutrients, especially AA. This could positively affect production of cows fed SDP in a dosedependent manner, especially during early lactation (i.e., negative MP balance), because blood by-products are high in RUP (NRC, 2001) compared with soybean meal. In addition, Jiang et al. (2000) reported increased utilization efficiency of AA in the gut because of lowered AA catabolism when SDP replaced extruded soy protein in pigs. Furthermore, ileal digestibility of all AA from SDP was greater than BM in pigs (Almeida et al., 2013). However, the generally similar plasma AA profile plus similar milk protein production between 100BM and 100SDP in the current study suggest that AA supply did not differ greatly between those 2 treatments. Although treatment effects on plasma AA concentrations (on d 14 of lactation for multiparous cows) were limited, some AA were affected. The observed differences may simply reflect differences in AA composition between BM and SDP (i.e., His, Val, Gln, and Gly concentrations). The AA composition of BM and SDP used in the current study (Supplemental Table S1; https://doi.org/10.3168/jds.2017-13795) is almost identical to that reported by Almeida et al. (2013). Increases in Thr and Trp for 400SDP versus 100SDP were probably due to greater concentrations of those AA in SDP versus the soybean meal product that was replaced with SDP (NRC, 2001). Plasma AA concentrations can be affected by various factors, which makes interpretation difficult. Amino acid supply (e.g., dietary AA, rumen undegradability, intestinal absorption) and AA utilization in tissues (oxidation and protein synthesis) are the major factors determining plasma AA concentrations (Doepel and Lapierre, 2010). During the first $21 \mathrm{~d}$ of lactation, DMI of multiparous cows (only multiparous cows were used for plasma AA profile) tended to be greater $(20.7$ vs. $19.8 \mathrm{~kg} / \mathrm{d} ; \mathrm{SE}=0.41$; $P=0.06$; data not shown) for 100SDP compared with BM without a difference between 100SDP and 400SDP. Differences in DMI and AA composition in the diets may have altered plasma AA concentrations. However, dietary AA supply and utilization by tissues was not determined, and fully understanding the changes in certain plasma AA concentrations observed in the current study is difficult. Nevertheless, the increase in milk protein yield with increasing inclusion of SDP indicates that metabolizable AA supply was increased.

Among EAA, the clear decrease in plasma His concentration for 100SDP compared with 100BM was likely due to low His content of SDP compared with BM and soybean meal (Supplemental Table S1, https://doi.org/ 10.3168/jds.2017-13795; NRC, 2001). Increases in His supply can increase feed intake, resulting in increasing milk yield, especially when provided with a proteindeficient diet to dairy cows (Kim et al., 1999; Lee et al., 2012; Giallongo et al., 2015). The lack of a difference in overall DMI between treatments indicates that His was 
not deficient for cows fed SDP. In addition, DMI for the high-His diet (100BM) was actually lower compared with that for the low-His diet (SDP) during the first 21 $\mathrm{d}$ of lactation, suggesting that the effect of differing His supply between BM and SDP on DMI was minimal in the current study.

Increased blood plasma and urinary 3-methyl-L-histidine concentrations are generally accepted as indicators of muscle protein breakdown (Sawada et al., 2013; Giallongo et al., 2015). Plasma 3-methyl-L-histidine for SDP was not different among treatments; however, plasma 3-methyl-L-histidine was numerically but consistently lower for 100SDP and 400SDP compared with $\mathrm{BM}$, which generally agrees with treatment effects on BW change in early lactation (Table 6). However, BW losses and 3-methyl-L-histidine concentrations were not correlated $(P=0.75$; data not shown). If feeding SDP did reduce muscle catabolism, it could be caused by increased supply of AA to the tissues. In nonruminants (weanling pigs), ileal digestibility of all AA in SDP was much greater than that of AA in avian and porcine BM (Almeida et al., 2013). A tendency of decreased

Table 10. Effect of feeding spray-dried plasma (SDP) or blood meal (BM) on milk fatty acid profile at 21 DIM $^{1}$

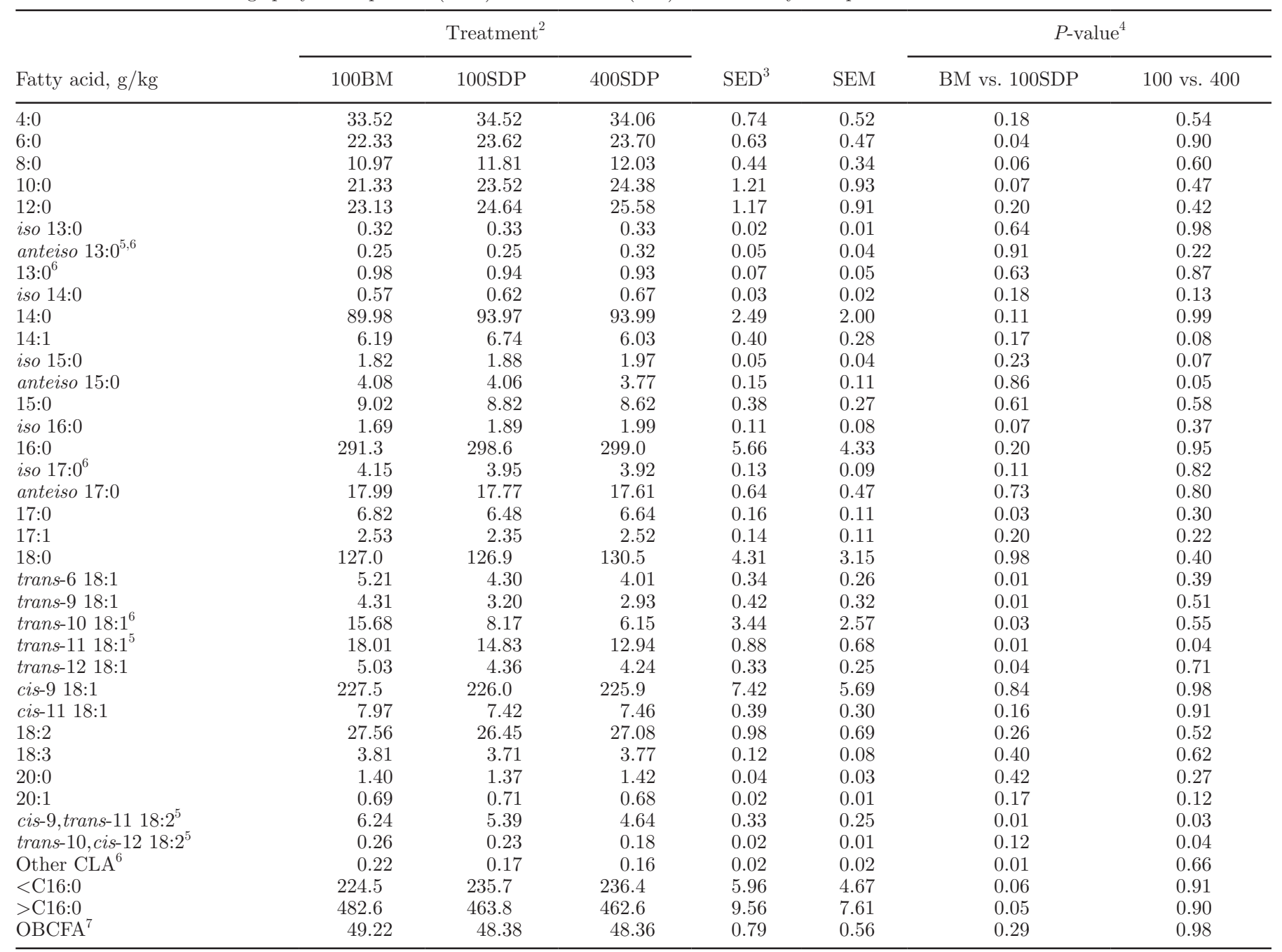

${ }^{1}$ Significant time effect $(P<0.05)$ was observed for all variables except trans-6 18:1, trans-9 18:1, trans-11 18:1, 18:2, trans-10,cis-12 18:2, and other CLA.

${ }^{2} 100 \mathrm{BM}=100 \mathrm{~g} / \mathrm{d}$ of BM; $100 \mathrm{SDP}=100 \mathrm{~g} / \mathrm{d}$ of SDP; 400SDP $=400 \mathrm{~g} / \mathrm{d}$ of SDP.

${ }^{3}$ Standard error of the difference.

${ }^{4} \mathrm{BM}$ vs. $100 \mathrm{SDP}=100 \mathrm{BM}$ vs. $100 \mathrm{SDP} ; 100$ vs. $400=100 \mathrm{SDP}$ vs. $400 \mathrm{SDP}$.

${ }^{5}$ Interaction of parity $\times$ treatment, $0.05<P<0.10$.

${ }^{6}$ Interaction of day $\times$ treatment, $0.05<P<0.10$.

${ }^{7}$ Odd- and branched-chain fatty acids $(\mathrm{FA})=$ total ante FA + total iso FA + 13:0 + 15:0 + 17:0 + cis-17:1. 
plasma 1-methyl-L-histidine with increasing SDP was observed in the current study. The source and role of 1-methyl-L-histidine, especially in cattle, is not clearly understood. No correlation $(P=0.18$; data not shown $)$ was observed between BW losses and 1-methyl-L-histidine concentrations in blood. In humans, urinary excretion of 1-methyl-L-histidine is probably not associated with dietary His supply but is highly related to dietary 1-methyl-L-histidine supply (Sjölin et al., 1987). Therefore, the decreases in plasma 1-methyl-L-histidine with greater SDP likely indicate relatively low 1-methyl-Lhistidine concentration in SDP compared with feeds it replaced.

The concentrations of individual FA in milk in the current study at 21 DIM were within the range reviewed by Moate et al. (2007). Among milk FA, the reduced concentrations of trans-10,cis-12 CLA and trans-10 18:1 in milk from cows fed SDP compared with $\mathrm{BM}$ can be biologically important because these specific FA are known as inhibitors of milk fat synthesis in the mammary gland (Jenkins and Harvatine, 2014). An inverse relationship exists between concentrations of trans-10,cis-12 CLA in milk and milk fat yield (de Veth et al., 2004). However, milk fat content and yield were not affected by SDP versus BM during the first $21 \mathrm{~d}$ of lactation when the milk sample was collected (d 21) for the FA profile.

Increases in shorter-chain FA $(<16 \mathrm{C})$ and decreases in longer-chain FA $(>16 \mathrm{C})$ in milk from cows fed SDP versus $\mathrm{BM}$ indicate increased de novo synthesis of $\mathrm{FA}$, decreased mobilization of long-chain FA, or both. Longchain FA, which are derived from dietary fat and fat mobilization from adipose tissues, can decrease de novo synthesized FA (<16 C) in milk (Drackley, 1999). Cows fed 100BM may have mobilized more fat from body reservoirs compared with SDP according to BW changes (Tables 6 and 8). However, the difference in BW change was not significant during the first $21 \mathrm{~d}$ when milk samples were collected for FA profile. This may be because of greater cow-to-cow variation in BW change than milk FA profile. De novo synthesis of short-chain FA may have differed between BM and SDP because differences were observed in concentrations of trans-10 18:1 and trans-10,cis-12 CLA (Table 10). However, the concentrations of those FA, especially trans-10, cis-12 CLA, are within the range observed in normal (i.e., no milk fat depression) milk (Rico et al., 2015; Leduc et al., 2017; Ma et al., 2017). Increases in those trans FA in milk are often associated with decreased concentrations of $<16 \mathrm{C}$ and increased concentrations of $>16$ $\mathrm{C}$ in milk (Rico et al., 2015; Ramirez-Ramirez et al., 2016). However, the reason why diet affected trans-10 18:1 or trans-10,cis-12 CLA is unknown.

\section{CONCLUSIONS}

Replacing $100 \mathrm{~g}$ of BM with $100 \mathrm{~g}$ of SDP increased concentrations of milk components but not yields, suggesting that BM and SDP have similar nutrient value or that inclusion rates were not high enough to cause an effect. However, feeding approximately $400 \mathrm{~g} / \mathrm{d}$ of SDP increased milk and milk component yields without a concomitant increase in feed intake compared with feeding $100 \mathrm{~g}$ of SDP/cow per day, suggesting potential improvements of digestive or metabolic efficiency. The mode of action for increased efficiency of milk production was not determined. However, it was not caused by greater mobilization of body reserves. Studies evaluating effects of SDP on the gut microbiome, gut health, and immune function may be needed to determine mode of action in dairy cows.

\section{ACKNOWLEDGMENTS}

The authors express appreciation to Donna Wyatt for conducting laboratory assays and to Brent Hostettler and the crew at the Krauss Dairy Center (both at OARDC in Wooster). This project was supported in part by a grant from APC Inc. (Ankeny, IA) and by state and federal funds appropriated to the Ohio Agricultural Research and Development Center, Wooster.

\section{REFERENCES}

Almeida, F. N., J. K. Htoo, J. Thomson, and H. H. Stein. 2013. Comparative amino acid digestibility in US blood products fed to weanling pigs. Anim. Feed Sci. Technol. 181:80-86.

Ametaj, B. N., Q. Zebeli, S. Iqbal, and S. M. Dunn. 2012. Meeting the challenges of improving health in periparturient dairy cows. Adv. Dairy Technol. 24:287-317.

AOAC International. 2000. Official Methods of Analysis. Vol. 1 and 2. AOAC International, Gaithersburg, MD.

Bach, A., J. Polo, J. M. Campbell, M. E. de Haro Marti, and M. Chahine. 2017. Effects of spray-dried plasma product supplementation on transition and lactation on milk production and reproduction in dairy cows. J. Dairy Sci. 100(Suppl. 2):236. (Abstr.)

Bell, A. W., W. S. Burhans, and T. R. Overton. 2000. Protein nutrition in late pregnancy, maternal protein reserves and lactation performance in dairy cows. Proc. Nutr. Soc. 59:119-126.

Beski, S. S. M., R. A. Swick, and P. A. Iji. 2016. The effect of the concentration and feeding duration of spray-dried plasma protein on growth performance, digestive enzyme activities, nutrient digestibility and intestinal mucosal development of broiler chickens. Anim. Prod. Sci. 56:1820-1827.

Campbell, J. M., J. D. Crenshaw, L. E. Russell, and S. K. Hayes. 2008. Influence of dietary plasma proteins on supporting animal immunity systems. Florida Ruminant Nutrition Symposium, Gainesville, FL.

Coffey, R. D., and G. L. Cromwell. 1995. The impact of environment and antimicrobial agents on the growth-response of early-weaned pigs to spray-dried porcine plasma. J. Anim. Sci. 73:2532-2539.

de Veth, M. J., J. M. Griinari, A. Pfeiffer, and D. E. Bauman. 2004. Effect of CLA on milk fat synthesis in dairy cows: comparison of inhibition by methyl esters and free fatty acids, and relationships among studes. Lipids 39:365-372. 
De Gracia, M., F. G. Owen, and S. R. Lowry. 1989. Corn gluten meal and blood meal mixture for dairy cows in mid lactation. J. Dairy Sci. 72:3064-3069.

Doepel, L., and H. Lapierre. 2010. Changes in production and mammary metabolism of dairy cows in response to essential and nonessential amino acid infusions. J. Dairy Sci. 93:3264-3274.

Drackley, J. K. 1999. ADSA Foundation Scholar Award. Biology of dairy cows during the transition period: The final frontier? J. Dairy Sci. 82:2259-2273.

Dritz, S. S., K. Owen, R. D. Goodband, J. L. Nelssen, M. D. Tokach, M. M. Chengappa, and F. Blecha. 1996. Influence of lipopolysaccharide-induced immune challenge and diet complexity on growth performance and acute-phase protein production in segregated early-weaned pigs. J. Anim. Sci. 74:1620-1628.

Fahey, J. L., and E. M. McKelvey. 1965. Quantitative determination of serum immunoglobulins in antibody agar plates. J. Immunol. 94:84-90

Giallongo, F., A. N. Hristov, J. Oh, T. Frederick, H. Weeks, J. Werner, H. Lapierre, R. A. Patton, A. Gehman, and C. Parys. 2015. Effects of slow-release urea and rumen-protected methionine and histidine on performance of dairy cows. J. Dairy Sci. 98:3292-3308.

Gisbert, E., A. Skalli, J. Campbell, M. M. Solovyev, C. Rodriguez, J. Dias, and J. Polo. 2015. Spray-dried plasma promotes growth, modulates the activity of antioxidant defenses, and enhances the immune status of gilthead sea bream (Sparus aurata) fingerlings. J. Anim. Sci. 93:278-286.

Grant, R. J., and S. G. Haddad. 1998. Effect of a mixture of feather and blood meals on lactational performance of dairy cows. J. Dairy Sci. 81:1358-1363.

Hailemariam, D., R. Mandal, F. Saleem, S. M. Dunn, D. S. Wishart, and B. N. Ametaj. 2014. Identification of predictive biomarkers of disease state in transition dairy cows. J. Dairy Sci. 97:2680-2693.

Heinze, C. R., J. A. Larsen, P. H. Kass, and A. J. Fascetti. 2009. Plasma amino acid and whole blood taurine concentrations in cats eating commercially prepared diets. Am. J. Vet. Res. 70:1374-1382.

Jenkins, T. C. 2000. Feeding oleamide to lactating Jersey cows 1. Effects on lactation performance and milk fatty acid composition. J. Dairy Sci. 83:332-337.

Jenkins, T. C., and K. J. Harvatine. 2014. Lipid feeding and milk fat depression. Vet. Clin. Food Anim. 30:623-642.

Jiang, R., X. Y. Chang, B. Stoll, M. Z. Fan, J. Arthington, E. Weaver, J. Campbell, and D. G. Burrin. 2000. Dietary plasma protein reduces small intestinal growth and lamina propria cell density in early weaned pigs. J. Nutr. 130:21-26.

Kim, C. H., J. J. Choung, and D. G. Chamberlain. 1999. Determination of the first-limiting amino acid for milk production in dairy cows consuming a diet of grass silage and a cereal-based supplement containing feather meal. J. Sci. Food Agric. 79:1703-1708.

Larsen, M., C. Galindo, D. R. Ouellet, G. Maxin, N. B. Kristensen, and H. Lapierre. 2015. Abomasal amino acid infusion in postpartum dairy cows: Effect on whole-body, splanchnic, and mammary amino acid metabolism. J. Dairy Sci. 98:7944-7961.

Leduc, M., R. Gervais, and P. Y. Chouinard. 2017. Effect of calcium salts of polyunsaturated fatty acids with different particle sizes on lactation performance and milk fatty acid profile in dairy cows. J. Dairy Sci. 228:102-114.

Lee, C., A. N. Hristov, T. W. Cassidy, K. S. Heyler, H. Lapierre, G. A. Varga, M. J. de Veth, R. A. Patton, and C. Parys. 2012. Rumen- protected lysine, methionine, and histidine increase milk protein yield in dairy cows fed a metabolizable protein-deficient diet. J. Dairy Sci. 95:6042-6056

Ma, G., J. H. Harrison, E. Block, T. C. Jenkins, and L. VanWieringen. 2017. Short communication: Temporal effect of feeding potassium carbonate sesquihydrate on milk fat in lactating dairy cows fed a fat-depressing diet. J. Dairy Sci. 100:371-378.

Mancini, G., A. O. Carbonara, and J. F. Heremans. 1965. Immunochemical quantitation of antigens by single radial immunodiffusion. Immunochemistry 2:235-254.

Moate, P. J., W. Chalupa, R. C. Boston, and I. J. Lean. 2007. Milk fatty acids. I. Variation in the concentration of individual fatty acids in bovine milk. J. Dairy Sci. 90:4730-4739.

NRC. 2001. Nutrient Requirements of Dairy Cattle. 7th rev. ed. Natl. Acad. Sci., Washington, DC.

Ospina, P. A., D. V. Nydam, T. Stokol, and T. R. Overton. 2010 Evaluation of nonesterified fatty acids and beta-hydroxybutyrate in transition dairy cattle in the northeastern United States: Critical thresholds for prediction of clinical diseases. J. Dairy Sci. 93:546-554.

Pérez-Bosque, A., J. Polo, and D. Torrallardona. 2016. Spray dried plasma as an alternative to antibiotics in piglet feeds, mode of action and biosafety. Porcine Health Manag. 2:16-25.

Pires, A. V., M. L. Eastridge, and J. L. Firkins. 1996. Roasted soybeans, blood meal, and tallow as sources of fat and ruminally undegradable protein in the diets of lactating cows. J. Dairy Sci. 79:1603-1610.

Ramirez-Ramirez, H. A., E. Castillo Lopez, C. J. R. Jenkins, N. D. Aluthge, C. Anderson, S. C. Fernando, K. J. Harvatine, and P. J. Knonoff. 2016. Reduced-fat dried distillers grains with solubles reduces the risk for milk fat depression and supports milk production and ruminal fermentation in dairy cows. J. Dairy Sci. 99:1912-1928.

Rico, D. E., A. W. Holloway, and K. J. Harvatine. 2015. Effect of diet fermentability and unsaturated fatty acid concentration on recovery from diet-induced milk fat depression. J. Dairy Sci. 98:79307943.

Sawada, K., K. Nagano, and N. Nishino. 2013. Plasma 3-methylhistidine concentration in peripartum dairy cows given diets with two protein levels. J. Anim. Vet. Adv. 12:712-717.

Sjölin, J., G. Hjort, G. Friman, and L. Hambraeus. 1987. Urinary excretion of 1-methylhistidine: A qualitative indicator of exogenous 3 -methylhistidine and intake of meats from various sources. Metabolism 36:1175-1184.

Song, M., Y. Liu, J. J. Lee, T. M. Che, J. A. Soares-Almeida, J. L. Chun, J. M. Campbell, J. Polo, J. D. Crenshaw, S. W. Seo, and J. E. Pettigrew. 2015. Spray-dried plasma attenuates inflammation and improves pregnancy rate of mated female mice. J. Anim. Sci. 93:298-305.

van Dijk, A. J., H. Everts, M. J. A. Nabuurs, R. J. C. F. Margry, and A. C. Beynen. 2001. Growth performance of weanling pigs fed spray-dried animal plasma: A review. Livest. Prod. Sci. 68:263-274

Weiss, W. P., and D. J. Wyatt. 2003. Effect of dietary fat and vitamin $\mathrm{E}$ on $\alpha$-tocopherol in milk from dairy cows. J. Dairy Sci. $86: 3582-3591$ 